\title{
Ideological Constructs - Past Visions/ Future Possibilities: evaluating the endangered subjects in the context of emerging global sustainability and environmental agendas
}

\author{
By Mary Loveday Edwards
}

Mary Loveday Edwards is a lecturer in Critical, Contextual and Historical Studies at Plymouth College of Art, a small specialist art college in the UK.

\begin{abstract}
In searching for reasons why the applied arts might be considered 'endangered subjects', this project's research proposal hypothesised that the applied arts were endangered subjects not necessarily for reasons of progression. Other research speculates that primary and secondary schools have in the past phased out or abandoned craft subjects, and that students therefore did not think to choose crafts at tertiary level. However, this research posited that the crafts subjects were endangered not because they were off the schools' radars but because they were off the radar of a wider society: that they had lost their ideological impulse.
\end{abstract}

The single most important point to emerge from the project was the need to make explicit, to understand, and to develop, the empowering social-symbolic relationships that surround 'craft' as a construct forged between sets of practices, materials and 'communities'. This paper traces the project from inception to completion and discusses the findings.

\section{Paper}

'Ideological Constructs - Past Visions/Future Possibilities: evaluating the endangered subjects in the context of emerging global sustainability and environmental agendas' is a research project, funded by the National Arts Learning Network and Plymouth College of Art.

The National Arts Learning Network (NALN) was a four-year, Higher Education Funding Council for England (HEFCE)-funded widening participation initiative, comprised of specialist art, design and performing arts institutions, working together to widen participation in higher education. One of the areas in which NALN was involved was to look at the category of Endangered Subjects at art and design institutions in the United Kingdom (UK) and to examine the reason for their supposed decline. The Endangered Subjects were defined as 'those traditional subjects for which the overview of application data evidences a 
consistent decline; for which there is a fragile employment sector; and within which continued course provision is perceived to be at risk' (Wright, 2009: 4). The definition emphasised craft but did not exclude art forms such as traditional dance and drama, and included as wide a range of disciplines as possible. Among these were bookbinding, stonewalling, jewellery, traditional song, willow work, and automata. Anecdotal evidence from higher education educators, along with other NALN-supported research, speculates that primary and secondary schools have in the past phased out or abandoned craft subjects or courses, and that students therefore did not think to choose crafts at tertiary level. This, along with the cost of providing applied arts education and the subsequent closing down of several (often prominent) schools and departments offering this provision across the UK in the past few years, is one strongly supported area of advocacy. However, it could also be that the applied arts were endangered subjects not necessarily for reasons of progression.

This research project based at Plymouth College of Art posited that the crafts subjects were endangered not because they were off the schools' radars but because they were off the radar of a wider society: that they had lost their ideological impulse. The hypothesis is that emerging environmental and sustainability socio-cultural and economic forces might lead to, and might already be supporting, the development of new socio-ideological rationales that could help redefine and reconstitute the applied arts as less marginal, more centrally productive forces in society. The central question is whether environmental and sustainability issues provide ground for a public re- engagement with applied arts practice.

There are, of course, a number of ways of examining and defining these environmental and sustainability issues. The definition of sustainability itself is contested. One widely accepted definition is that developed by the World Commission on Environment and Development (1987). This defines sustainability as designing our lives, work, products, social systems, and relationships to meet the needs of the present without compromising the ability of future generations to meet their own needs. (This is a fairly good definition, with the qualification that most people, and certainly institutions, are hard pushed to think more than two future generations in the future. Thinking seven generations ahead might allow us to think both more broadly and with more clarity about the consequences of our current actions. Certainly examining our actions with regard to the effect on even two generations ahead gives a far wider result than thinking in periods governed by the span of a term in political office.)

Breaking down the terms of reference further, and in particular allusion to this research, there are three main ways in which we might talk about sustainability: economic, social, and ecological. It can be a useful tool to examine these areas separately; however real sustainability requires environmental, social and economic demands - the 'three pillars' of sustainability - to be integrated or reconciled. This is not merely a question of a form of auditing or accounting but entails a mental, emotional, cultural and systemic shift. 
Ecological sustainability can be defined as the ability of an ecosystem to maintain ecological processes, functions, biodiversity and productivity into the future. Several measures of human interaction with ecologies show that economic growth is adversely tied to ecological degradation. Though a majority of scientific opinion has, in a few short years, recognised human-made global warming, there are no serious dissenters to the notion that we cannot, globally, continue in our consumption patterns. When 'natural capital' (the sum of the earth's resources) is used up faster than it can be replenished, the situation is unsustainable. The understanding that this is the situation we face at the moment is at the implicit heart of this research.

Social sustainability means meeting the needs of the present without compromising the ability of future generations to meet their own needs. This definition contains within it two key concepts:

'The concept of needs, in particular the essential needs of the world's poor, to which overriding priority should be given, and: the idea of limitations imposed by the state of technology and social organization on the environment's ability to meet present and future needs.' (1987)

In other words, both the technology that we use and the social structures within which we operate can be damaging ecologically. Conversely, by paying attention to the needs of all, rather than the desires of certain wealthy sections of certain wealthy nations, and by investigating the role of technologies and of social structures, we can identify and move towards less damaging and more sustainable cultural values and behaviours.

In an economic sense, a business is sustainable if it has adapted its practices for the use of renewable resources and is accountable for the environmental impacts of its activities. Much attention is given to the need to make profits - to appease the shareholders, as it were. Sustainability in economic terms entails acknowledging that there are more stakeholders than those who benefit from the profits made by a business. Mere fiscal sustainability is often the meaning implied when companies and institutions talk about economic sustainability: that is, that they will be able to continue with current or even greater levels of economic growth, a situation at odds with ecological sustainability. 'Sustainable growth' is an oxymoron; it merely means growt in a less ecologically damaging way. This idea of growth as a concept being problematic is a debate which is often ignored, since it strikes at the heart of many Western institutions, and particularly financial ones. These have been allowed to run unchecked, unexamined, for many years now, so that they have a hegemonic hold over us. We simply cannot see how we might change them.

It is important to understand how damaging the pervasive influence of making all decisions based around ideas of market value, as if they are the only or most important notions involved. As Michael Sandel, Reith lecturer in 2009 said,

'Some of the good things in life are corrupted or degraded if turned into commodities, so to decide when to use markets, it's not enough to think 
about efficiency; we have also to decide how to value the goods in question. Health, education, national defence, criminal justice, environmental protection and so on - these are moral and political questions, not merely economic ones.'

Economic reality is important. But despite over-reliance on economic measurements as indicators of success, or otherwise, at micro and macro levels, it is not the only important judgement criteria. Taking into account primary stakeholders, such as stockholders, customers, and employees, and secondary stakeholders - anyone who can be affected by the actions of a company - changes the scope of the sphere of influence of a business. If we widen the idea of stakeholder to include not only people but also environments, we are moving more towards a situation in which the three pillars of sustainability are mutually reinforcing rather than mutually exclusive. Sustainability can be a property of living systems, a manufacturing method, or a consideration as to a way of interpreting life. There are many accounts that seem to attempt to 'read' sustainability more narrowly, using only one of the three 'pillars' outlined above; but it is clear that the notion is only complete if it does take all three areas into consideration. This is also useful for looking at debates around sustainability as a lens through which we might view the applied arts.

Initially the research project was drawn towards an engagement with and evaluation of historical craft movements. People seemed to be looking to some historical periods for ideological inspiration, which appeared to validate the original framing of the research ideas. There are even today in craft many parallels with the Arts and Crafts movement, Bauhaus, and other ideologically strong (or even ideologically-led) movements. The socio-cultural nature of the research focus was underlined by Gillian Naylor's (1971: xiv) study of The Arts and Crafts movement:

'(It) was inspired by a crisis of conscience. Its motivations were social and moral, and its aesthetic values derived from the conviction that society produces the art and architecture it deserves...their endeavours were directed, ultimately, towards a social end, the establishment of a society in which all men would enjoy the freedom to be creative. Their concern, therefore, was not focused exclusively on end-products but on the society that shaped them, the men who designed and made them and on the people who bought them...to work towards the creation of an environment that would both serve and express people's needs...'

The social and symbolic values given to the Applied Arts forms an important aspect to their significance. Bernard Leach and Shoji Hamada made talk about integrity and the emotional pull of the handmade acceptable within ceramics, not only circumventing the more quantitative or economic debates but also providing a counterpoint to Veblen's (1899) critique of the indecorous luxury of the unique and exclusive. When we ask that difficult question, what justification do you have for adding more objects to the world(?), we might talk in terms popularised by Leach, and by those who currently reinterpret the spirit of his words (in Williams, 2002: 62). 
'The term 'lasting value' ... can mean the use of high quality materials and techniques to ensure the longevity of an object. It can mean finding an afterlife for materials or components that would otherwise be discarded... But it can also mean the perpetuation of traditions and conventions valued in the past, now threatened by social, economic or other changes. Similarly, the phrase can pertain to the spiritual or symbolic meanings inherent in objects, such as their emotional associations or individual characteristics. For a discussion of craft, it must also mean the added value in a handmade object that we preserve and respect above massproduced commodities.'

Craft, here, is about process, an approach to process as opposed to concentrating on objects produced. This approach to the notion of craft can be related to a developmental approach. Work on sustainability in education and the importance of nature on child development provides interesting findings. Many researchers across a variety of disciplines are currently absorbed in looking at the need for children to havelimits in their life - the need for them to test the limits of structures such as parental authority (including physical horseplay), the limits of their physical skills (the implication being that, in an increasingly sheltered and sedentary world they do not get to do so), the limits of a safe interaction with the world around them. More and more in a health- and-safety obsessed world, it is being observed that children are not being allowed to experience any of the above limits, and that this is adversely impacting their development. We may be entering a time when the only limits a child experiences are the limits of materiality: how far a piece of wood can be bent before it breaks; how clay behaves under stress. If these experiences in school are taken away, the child may not be experiencing any limits at all. As Piaget in his work on child development proved, concrete experience is necessary before abstraction can occur. Richard Sennett in The Craftsman writes about the effect of CAD systems on design, and yet in schools it seems we are often expecting students to work purely in abstraction without experience of the concrete. Would we expect a child to do abstract maths without concrete experience?

In fact Eugene S. Ferguson's (1992: 107) critique of modern engineering science examines this as a wider problem than just for schools. Rather than working from mathematical computation, skilled engineers with hands-on drawing and modelling experience formulated drawings ithe 'mind's eye' which became three dimensional models that supplied builders with non-verbal, sensual, qualitative information - visual, tactile, muscular, and aural.'

It seems the experience of handling materiality is necessary for everyone not just for rehabilitation or occupational therapy - it is necessary for all as a developmental urgency (in Sigman, 2008).

'In another study of 10,000 children, using a standard test of perceptions of volume and weight, considered a fairly robust indicator of cognitive development, researchers have concluded...'the performance of students has recently been getting steadily worse. An 11-year-old today is performing at the level an 8- or 9-year-old was performing at 30 years 
ago....in terms of cognitive and conceptual development ... The most likely reasons are the lack of experiential play in primary schools, and the growth of a video-game, TV culture. Both take away the kind of hands-on play that allows kids to experience how the world works in practice and to make informed judgements about abstract concepts...'

New neuro-scientific research such as The Neural Bases of Complex Tool Use in Humans (Johnson-Frey, 2004) is finding that using tools such as those in craft activities, involves the use and strengthening of 'widely distributed, yet highly interactive, [brain cell] networks'. Furthermore this tool use - described as 'complex, real-world behaviours' - involves and stimulates 'social, cognitive, perceptual and motor processes.' By using tools in this way, mirror neurons - specialised brain cells involved in observational learning and/or copying by example are activated. This is part of a greater civilising process, which serves 'as a critical mechanism for the cultural transmission of skills'.

In other words, without direct and sustained experience of materials - a fundamental of craft - the brain is underdeveloped. Moreover, the tacit knowledge that develops through working with materials has been the subject of critical discourse, perhaps most notably Schon's theory of reflection-in-action. Sennett (2009) extrapolates further on the social benefits of material thinking:

'The craft of making physical things provides insight into the techniques of experience that can shape our dealings with others...Material challenges like working with resistance or managing ambiguity are instructive in understanding the resistances people harbour to one another or the uncertain boundaries between people.'

In other words, material experiences and thinking can affect social experiences and thinking. This is an issue concerning sustainable societies. But there are issues for crafts beyond the socio- or human-centric.

There are some environmental philosophies, which aim to fundamentally alter the relationship of humans to the natural world. Deep Ecology is a way of looking at the natural world which recognises that humans are members of an interdependent community that includes not only humans, but, as Aldo Leopold (1987: 204) said, 'soils, waters, plants and animals, or collectively: the land.' It is a subtle but major shift in perception to see a clean environment that supports health as a right for all life forms, not just that of humans. Deep Ecology sees that all disciplines, cultures, classes, genders, communities, and species, have something to add to the design of solutions that work for everyone. If we believe in this way of looking at the world, it becomes even more imperative that we close the gap between what we believe and the way we behave in the world.

This might manifest in public sensibility (at least initially) by aesthetic values of balance; of social and ecological justice overriding concern with the generation of capital; or, indeed, with our individual concern with consumption. Corporate culture and the media machine are overwhelmingly concerned with the creation of desire. All are aware, no doubt, of this manipulation of desire; very few are 
immune to it. But if people generally used sustainability as the benchmark or standard of their consumption patterns, it would certainly impact, in ways potentially both positive and negative, on applied artists. In The Masterless Way: Weaving an Active Resistance, Faith Gillespie (1987: 178) describes the craftsperson's position:

'There is clearly another imperative at work now in our exercise of the old crafts. It has to do with reclamation, with reparation. The world seems not to need us any more to make 'the things of life.' Machines make more and cheap. The system needs us to do the maintenance jobs and to run the machines that produce the so-called 'goods', to be machines in the consumer societies, which consume and consume and are empty. Our turning to craftwork is a refusal. We may not all see ourselves this way, but we are working from a position of dissent. And that is a political position.'

Craft as a politically resistant undertaking entails a deeper debate than that concerned with manufacturing craft out of renewable materials. Many publications emphasise the fact that the roots of sustainability lie in culture rather than materials, although it is in the area of resource use that most sustainability issues are most often and most publicly debated. Recycling, renewables, mining conditions, ecological degradation, and so on, are in the public consciousness, with, for example, ethical jewellery companies Adili, Ingle\& Rhode, and The Leakey Collection all basing their marketing on the ethical credentials surrounding their resource relationships.

What does this mean for applied artists? Does it mean that we make objects to last? That we therefore perhaps make fewer objects? That we make objects that last in terms of component parts, a cradle-to-cradle stance in terms of what we produce? Does it mean that we look at the idea of re-imbuing the crafts with the values of the handmade, tracing a tradition and a value through time, history, and a shared humanity? Do we look at crafts as a political site of dissent; say that although we don't need to make any more objects by hand, we do it anyway because we reject the emptiness of endless consumption? Do we look at crafts as a process rather than place so much emphasis on the product? Or can the idea of personal development via making or consuming crafts survive the taint of the amateur? The intention of the research project was to challenge and refine positions with concrete case studies from the contemporary applied arts (initially in the UK) which exhibit practices, identities, positions and markets that strongly relate them to the environmental and sustainability fields, in order to help identify key issues, tendencies and trends, possibilities and opportunities.

One of the tools used in this project was a one-day workshop, consisting of six to eight invited participants. Each was asked to give an overview of their work, markets, and underlying ethos. There followed a discussion and debate between all the participants, based around the following closely overlapping areas:

1. Sourcing and consumption of materials. Potentially, this was the most obvious place to start: craftspeople make objects. In some circles that is 
the definition of crafts, and making objects involves materials. Initiatives such as fair trade, recycled materials, second hand metals, safety and sustainable mining and quarrying, or even using (only) renewable materials, were starting issues for exploring the case studies.

2. Location and identity. This issue centres on ideas of localised production and consumption, as opposed to trying to operate within global markets, or focusing on global trading practices. It might, for example, encompass various tourist or other local provenance issues.

3. The role of technology. The workshop discussion was designed to look at ideas of technology as benign or evil, as useful or alienating, and to assess its place in sustainable visions of craft practice. Technology can often be un-reflexively seen within the craft world as an enemy: Sennett (for example) in The Craftsman identifies that CAD technologies are being used instead of, rather than as an extension of, experience with real materials. But while technologies can be alienating, they can also mean the difference between making a living and not being able to.

4. Scales and methods of production in relation to making. This issue typically revolves around the contentious binary that sees the handmade as being more spiritual or "pure", and its opposite in industrial production as typically based upon an adulterated or soulless practice. Of course, this is not necessarily so: there are, for example, companies which, while employing industrial techniques and economies of scale, seek to encompass ethical approaches to their workforce, to their local communities, to ecological practices.

5. Individual developmental aspects of the applied arts; ways in which the developmental importance of the crafts are embodied in individuals; which links to:

6. Social values and social developmental aspects of the applied arts and ideological standpoints of practitioners in relation to the natural world. This issue centres on ideas of organization or collaboration, such as workers' collectives, but might also encompass those who see crafts as a form of 'social sculpture' and those who see the practice of craft as a form of protest, political statement, or other critical response to society.

Jane Hope, a jeweller, looked at the sourcing of raw materials in the context of fairtrade and ethical mining practices. Hope's research on artisan miners in Bolivia foregrounded the fact that when processes that are ecologically damaging are used in crafts they are very visible indeed. There are questions to be asked concerning the amount of ecological damage caused by mining when it is to be used for jewellery, a decorative item, compared with, say, agriculture, which is arguably more necessary. (This foregrounds and sharpens the arguments around agriculture rather than excusing agricultural practices as they stand; but the fair-trade initiative is common to them both.) Hope highlighted the need to work with mining companies rather than not engaging in dialogue. She pointed out that there are responsible mining companies whose goals are to improve 
the health and education of local communities and to eradicate child labour. The main problem identified is the lack of transparency in the supply chain and the need to educate the customer, which is seen as a marketing problem (or opportunity). Changing the way we access raw materials can mean smaller environmental impacts - but much larger positive social ones.

Clare Moloney, project manager of "River and Cloth", a community project centring on the River Wandle in South London and its historical association with the textile industry there (including William Morris's workshop), addressed developmental issues and community, and had an angle on the local. The River and Cloth project is working with ten schools, training teachers, and 18 community groups, including a city farm which is being used to grow vegetable dyes which would have been used historically. This is a local arts project that is being used to promote awareness of craft sustainability through education. It is an 18-month project that trains people to use and cascade their skills in order to leave a legacy. Moloney stated that there was an observable desire of the public to contribute to making a better society by using and making sustainable artefacts and processes. (She also stated that the current economic climate had engendered a revival of interest in the art of "making do".) The project she presented was concerned with education: to build market awareness; to build producer awareness; to build supplier awareness. The children and adults involved in the project would, it was hoped, become consumers with greater awareness also.

Abigail Thomas, a book artist who works with attention to the ideal of the handmade, was concerned with 'slow craft' ideals and with aspects of what might be termed spiritual dimension of practice and its manifestation as a political concern. According to Thomas, the fact is that advanced industrial societies are inherently dirty, exploitative and anti-natural; but they can be substantially improved if we decide to prioritise sustainable systems and then organise socially and politically around these systems.

\section{How might craft contribute to this?}

Jonathan Garrett, a potter with a studio that sells direct to the public, is concerned with using local clay and natural processes, and with the idea of craft as a political act or statement. Garrett was interested in the shift he has observed of people seeming to want to get back to nature. As he says on his website, 'some of us never left'. Garrett talked about his introduction to, and early experiences with, craft; in his view makers are their history. (This was an important point in the wider themes of the day, since many of the practices we looked at were concerned, centrally or peripherally, with self- empowerment and education.) He uses local clay and sells to local and passing tourist trade. He started as a craftsman in the 1970s, when crafts-based livelihoods were seen as serious political acts - a way into alternative lifestyles. He thought that politically and culturally, the crafts seem to have lost their way, and that sustainability might be the way for people to reconnect in an important way to 
crafts. If urban vegetable markets can take off, why not urban crafts? However, he thought that there was a serious lack of leadership in the field, and an urgent need for wider media and communications coverage.

Clara Vuletich, a printed textile designer and researcher at Textiles Environment Design (TED) Project (Chelsea College of Art \& Design, London), stated that craftspeople need to be educated to see how their product operates in a whole system and how their products can be agents of social change. Social change and marketing strategies are very closely linked. She sees the establishment of creative communities, "multi-local" societies (for example, joined by interests and not necessarily only geography) as essential. (Vuletich's blog, Love and Thrift, continues to chart many examples of points of contact between this research and her own).

Richenda Macgregor, Natalie Elder and Nick Kary were members of 'Sustainable Makers', the craft 'arm' of the Totnes Transition Town grass roots initiative which is based around the idea of preparing for, and transitioning to, a postpeak oil society and a sustainable future economy and way of life. Macgregor highlighted the sets of relationship that the maker exists within: with suppliers, with the material, with the client(s) and the public, with him or herself. These relationships provide a sustaining energy and also help overcome the isolation and sense of powerlessness of the maker. She talked of the need for the master craftsperson to 'deskill' oneself: too much skill, she felt, can separate one from life - people can be too in awe of crafts skills, whereas everyone can participate in making. She pointed to a need for re-skilling and skills exchanges, for coops where people can share equipment and tools. Re-skilling is often framed as a need to reconnect to 'nature', but re-skilling can also be seen as a way of reconnecting to the synthetic sustainable world: it is just as necessary for urban people to learn to adapt and change the material world in which they find themselves. Kary spoke of the need to develop a personal relationship with the word sustainability in order to be a functional part of the world. He recounted an initial training that had been all about emasculating the wood with which he worked, and of a subsequent process of coming to more of a partnership with the materials. Once again, however, the need for a supportive community to enable the move towards sustainability was a cornerstone.

During the ensuing discussions the question was raised whether, instead of finding a 'new' ideology linked to sustainability as the way to make craft relevant again, the 'ideology of craft' was in fact the central problem: 'craft' is automatically and un- reflexively seen as meaning 'natural' and remains unquestioned but also undeveloped and largely irrelevant to a community further and further removed from nature. This ideological slant - and the one which says 'craft' means making things by hand, need to be challenged.

Relationships (with materials, with artefacts, with suppliers and buyers, and with each other) emerged strongly during this workshop as a major feature of crafts, as did the notion of developing a relationship with a local community. The importance of these relationships would seem to be central - that the 'ideology' 
of connection, of systems, could be the most important facet in the effort to make the contemporary crafts both more ecologically sustainable, and perhaps therefore more economically sustainable by becoming ever more relevant to a wider public. In fact, perhaps the single most important point to emerge was the need to make explicit, to understand, and to develop the empowering socialsymbolic relationships that surround 'craft' as a construct forged iteratively (or interactively) between sets of practices, materials and communities or social groups.

These relationships come together to create what seem, in effect, narratives of belonging made up of actual and imagined elements. Relationship and community were the two words that came up again and again, providing a common thread throughout the day. It was not necessarily the thread that had been expected; perhaps, forexample, more emphasis might have been expected to be placed upon physical, ecological options. But the participants all reiterated the fundamental importance of the relationships inherent in the crafts.

The obvious question is whether this concern was limited in time and place to one workshop. The 'Making Futures: the crafts in the context of emerging global sustainability agendas' International Research Conference was held on 17-18 September 2009 at Mount Edgcumbe Country House, close to the city of Plymouth. The conference was obviously closely tied to the research agenda of the project in this report. Here there was an opportunity to see if these relational concerns were widespread and international. I chaired one of the conference sessions (the socio-technological strand) and reported back to the full conference in the afternoon plenary session. Interestingly, perhaps especially for a strand, which ostensibly was dealing with technology, a real commonality was the importance and role of relationships within this strand. It has become very clear that, far from being about objects - how they look, whether they function, what aspect of aesthetics will be used to assess it craft is more concerned with context and the relationships engendered in its practice. As Paul Harper (2009) says,

'The primary critical and theoretical focus in the crafts has become the craft object as site of meaning and main area of significance. This essentially literary approach regards the object as something to be 'read'. I believe that this focus neglects those things that define craft as intrinsically connected to the material world, to experience and to practice...the craftsperson's intimate connection to materials, process, techniques, forms, and the traditions associated with these...the context in which things are made and consumed.'

Perhaps it seems retrospective to relate craft to a theoretical principle most often used in art: but if it is a theory which only seems to reside in art because nobody knows where else to put it, or because it was first identified as an alternative to gallery-based work, it may be acceptable. Relational aesthetics is a branch of art theory, which prioritises the idea of process and people over product. Written about (and named) initially by Nicholas Bourriaud, and expanded by 
writers such as Grant Kester, it can be seen as a development from the earlier 'social sculpture' work of Joseph Beuys. For example, Mary Anne Davis, a craft artist in Columbia, USA, sees her work in this way:

\begin{abstract}
What I'm doing when I make dinnerware is facilitating the people who buy my dishes to think more creatively about the way they entertain...I'm bringing people together. When I sell dishes it's to encourage people to build community and friendships by social networks, by having a lot of contact with each other...You know, buy a lot of dishes, have a lot of dinner parties, save the world.'
\end{abstract}

Davis considers the ideas of performance and conceptual artist Joseph Beuys to be truth rather than theory: 'Everyone is an artist and society is a sculpture,' she says. At the heart of the emptiness of modern life, Davis believes, is humanity's having lost track of art, of having created a disconnection by separating art from everyday life. (Piperato, 2004)

There are still many craftspeople for whom these ideas are valueless, meaningless, irrelevant. But in terms of craft and its alignment with issues of sustainability, this turn towards a social anthropological/material-cultural set of perspectives seems logical. A key objective of this project was to arrive at a clearer understanding of the performance of the applied arts in relation to sustainability agendas. If the crafts are to enact more ethically and environmentally sustainable practices, it will likely be through re- orientating and developing the relationships that surround them upon such practices. Another objective was to attempt to frame and understand the decline in public interest in applied arts. In fact it is not entirely certain that there is a decline in public interest. The focus at the beginning of the research was on studio crafts and their performance in the market place. But it has become clear through the life of the project that this is a simplistic and limited view of the role of crafts in the interest of the public. Just because people buy a cheap dinner service rather than a studio one does not mean they are disinterested in crafts: it is more likely to mean they can't afford a studio dinner service. It does not mean they are not concerned with the provenance of the clay or the rights of the workers, though there will probably always be people who are unconcerned about either. This may be more about disenfranchisement than disinterest. But people participate in crafts in many more ways than by buying them, and craftspeople can have a more exciting, more important and more central role in society than that of just making things to sell. As Johnson (1997: 93) states,

'[The crafts] are made out of a sense of touch, and invite a tactile response...a particular kind of communication for both producer and consumer...What is implied by craft production is an intimacy between producer/object, object/consumer, producer/consumer.'

One of the definitions of craft is that of a thing done well; it would be well done to remember it is not done alone. Systems theory - a key understanding in sustainability debates - sees everything in a web of relationships. If we accept that a craft practice concerned with sustainability is primarily concerned with 
relationships, the question then becomes how best to facilitate and develop these relationships. This question is now the focus of several investigations, including the next issue of craft + design enquiry, which is to be entitled Relational Craft and Design. Similarly, the next conference for Making Futures is subtitled 'the crafts as change maker in sustainably aware cultures'. The focus for the conference includes a significant investigative theme called Craft as Social Process which interrogates the fundamental importance of the social relationships that are inherent in many crafts related activities. This takes us into the territory of craft as an agent in social sustainability and asks how we make explicit craft as a facilitator of positive social change within the context of ethical and ecological sustainability. And a recent UK Crafts Council publication includes an examination of the work of craftspeople in relation to various kinds of relationships surrounding their careers (2010).

It seems that the findings of this research project have fed into a further investigative focus on relationships, which provides the next area to be explored. The two areas are strongly linked. Whether implicit or explicit, whether central or tangential to the craftsperson's practice, relationships are at the heart of sustainable crafts.

\section{Bibliography}

Bruntland, G. et al., 1987, Report of the World Commission on Environment and Development: Our Common Future. Transmitted to the General Assembly as an Annex to document A/42/427 - Development and International Cooperation: Environment. [Online] Available at http://www.un-documents.net/ wced- ocf.htm (Accessed 10 March 2011)

Ferguson, E., 1992, Engineering and the Mind's Eye. MIT Press

Gillespie, F., 1987, The Masterless Way: Weaving an Active Resistance. In: Elinor, G., Richardson, S., Scott, S., Thomas, A., and Walker, K., (eds) Women and Craft. London: Virago

Harper, P., Visual Intelligences. [online] Availableathttp://www.visualintelligences. com/paul-harper.html (Accessed 10 March 2011)

Johnson, P., 1997, Out of Touch: The Meaning of Making in the Digital Age. In Harrod, T., ed. Obscure Objects of Desire (Reviewing the Crafts in the Twentieth Century). London: Crafts Council

Loveday Edwards, M., 2011, Ideological Constructs - Past Visions/Future Possibilities: evaluating the endangered subjects in the context of emerging global sustainability and environmental agendas 
Kester, G., 2000, Socially Engaged Practice - Dialogical Aesthetics: A Critical Framework for Littoral Art. [online] Available at http://www.variant.org. uk/9texts/KesterSupplement.html (Accessed 10 March 2011)

Leopold, A., 1987, A Sand County Almanac, and Sketches Here and There. 1948, New York: Oxford University Press

Plymouth College of Art, 2009, Making Futures: The Crafts in the Context of Emerging Global Sustainability Agendas. Vol 1. ISSN 2042-1664 http:// makingfutures.plymouthart.ac.uk/journalvol1

Naylor, G., 1971, The Arts and Crafts Movement. London: Studio Vista

Piperato, S., 2004, Life in the Balance: A Bohemian Martha Stewart. Chronogram Magazine. Available at http://www.chronogram.com/issue/2004/07/ backbone/lifeinthebalance.php (Accessed 10 March 2011)

Sandel, M., 2009, Lecture 1, Markets and Morals. Reith lectures 2009: A New Citizenship. Transmission (9 June 2009), BBC Radio 4, transcription

Schon, D., 1983, The Reflective Practitioner. How professionals think in action. London: Temple Smith Schwarz, M. and Yair, K., 2010. Making Value: craft \& the economic and social contribution of makers. London: Crafts Council

Sennett, R., 2008, The Craftsman. London: Allen Lane

Sigman, A., 2008, Practically Minded: The benefits and mechanisms associated with a craft-based curriculum. Ruskin Mill Hill Trust (RMHT)

Veblen, T., 1899, The Theory of the Leisure Classes. 1994, New York: Dover Publications

Williams, G., 2002, Creating Lasting Values. In Greenhalgh, P. ed., The Persistence of Craft. London: A\&C Black

Wright, E., 2009, Endangered Subjects: A Review of Practice at Seven leading UK Universities. London: National Arts Learning Network

http://www.jonathangarratt.com/

http://www.thebrake.net/nick_kary_furniture.html 